Neveling, Patrick (2017), 'The Global Spread of Export Processing Zones and the 1970s as a decade of consolidation', in Knud Andersen and Stefan Müller (eds.), Changes in Social Regulation - State, Economy, and Social Protagonists since the 1970s (Oxford: Berghahn Books), 23-40.

C $\begin{array}{lllllll}\text { A } & \text { P T E R } & 1\end{array}$

\title{
The Global Spread of Export Processing Zones, and the 1970 s as a Decade of Consolidation
}

Patrick Neveling

\section{Introduction}

Much work by historians of the recent past focuses on the 1970s. Often, the decade is presented as one of radical rupture. ${ }^{1}$ In this respect, historians have aligned themselves with social scientists who have identified a change in the predominant global regime of capitalist accumulation - from Fordism to neoliberalism, for example. ${ }^{2}$ Increasingly, however, such clear-cut periodization of global history is being met with scepticism. For example, labour regimes for West German workers may have changed profoundly in the said period, but such a radical rupture does not apply to the experiences of the so-called Gastarbeiter - migrant workers who had been recruited during the 1950s and 1960s boom years. ${ }^{3}$ This meets earlier criticisms by social scientists who pointed to the diversity of patterns of capitalist accumulation to show that there was no radical rupture in the early 1970s, or that this rupture was partial at best. ${ }^{4}$ In what follows, I introduce a third perspective, which identifies the 1970 s as a period of consolidation.

An analysis of the global spread of export processing zones (EPZs) and special economic zones provides the empirical foundation for identifying the 1970s as a period of consolidation. My research shows how EPZs have spread since the foundation of the first such zone in Puerto Rico in 1947, 
just after the Second World War. ${ }^{5}$ Since then, EPZs have come to be a crucial feature of what is often called the neoliberal era. Known under a range of denominations, including free trade zones, foreign trade zones and special economic zones, EPZs have been set up mainly by so-called underdeveloped countries and regions. Their purpose is to attract manufacturing relocations in sectors such as garments and light consumer electronics, in which cheap labour is paramount for generating profit and where transport costs matter less than for bulkier items. In the early years, such relocations were from industrially advanced countries to underdeveloped countries. EPZs sought to attract investors with exceptional tax and customs holidays, state spending for industrial infrastructure, cheap, docile and non-unionized labour, and other factors facilitating accumulation that were increasingly hard to find in industrially advanced countries with Keynesian and Fordist regimes.

In sum, EPZs are emblematic of the high capital mobility and precarious working conditions that many social scientists and contemporary historians identify as core criteria for the radical rupture of the early 1970s. To substantiate an alternative reading of world history that sees the 1970s as a period of consolidation, I show how an increasing number of mainly postcolonial nation states have set up EPZs since 1945. This will reveal that many of the above listed and further features substantiating the notion of radical rupture were actually widespread much earlier. As the number of EPZs has increased over the years, relocations from one zone to another have become common practice, for example. In other words, industrial relocation on a South-South basis was as common in the early 1970s as was South-South economic cooperation. ${ }^{6}$ Nevertheless, the 1970s mark a turning point in the global spread of EPZs. This is because the very concept of an 'export processing zone' was coined in that decade, in both economic development practice and academic analysis.

In the academic world, Folker Fröbel, Otto Kreye and Jürgen Heinrichs were among the first to identify increasing relocations of garments and light consumer electronics production from industrially advanced countries to EPZs in developing countries. Empirical research on this phenomenon provided important evidence for identifying a 'New International Division of Labour' (NIDL) emerging in the 1970s. ${ }^{7}$ One central finding was that relocations to EPZs caused 'structural unemployment in industrialised countries and industrialisation in developing countries'.

Surprisingly, however, historians of the recent past discussing 1970s efforts in social forecasting have paid little attention to the NIDL concept or to the global spread of EPZs. Instead, Daniel Bell's 1970s books announcing a third industrial revolution and 'the coming of post-industrial societies' are popular references. ${ }^{9}$ In my view this is unfortunate, as many social scientists 
have pointed out that Bell's analysis was limited to the Western, industrially advanced capitalist sphere, an issue only recently considered among historians. ${ }^{10}$

This chapter makes use of the example of EPZs to move forward the critical engagement with the 1970s in two ways. First it outlines why and in what ways the common explanatory focus on a so-called "crisis of Keynesianism' fails to engage with the long-term causes of that crisis. ${ }^{11}$ It then summarizes development leading to and resulting from the establishment of the world's first EPZ regime in Puerto Rico. While this section highlights that practices commonly associated with neoliberalism and the 1970s and after were common in manufacturing relocations from the US mainland to Puerto Rico in the late 1940s, the next section shows how the EPZ became a standardized model for development in the 1970s when a working group of the United Nations Industrial Development Organization (UNIDO), concerned with 'Exports Promotion' (EP), surveyed EPZ-like activities worldwide and established the term 'EPZ'.

My concluding remarks introduce an explanatory model for understanding capitalism as a global system with competing models of accumulation operating at a given time. EPZs were part and parcel of a larger political initiative against Keynesian policies that emerged in reaction to New Deal policies of the 1930s. The global spread of such zones is, then, empirical evidence for the fact that global capitalism cannot be portrayed as a succession of eras, each dominated by a single coherent mode of accumulation. Instead, neoliberal and Fordist/Keynesian models of accumulation have been competing since the 1930s.

\section{The 1970s: Assessing and Contesting Historians' Notions of Radical Rupture}

The missing global perspective on the 1970s pointed out above is evidenced in Doering-Manteuffel and Raphael's work, for example. Around 1975 a 'social transformation of revolutionary quality' took place because three sets of changes that had so far developed along independent trajectories now coincided. These were 'digitalisation', the rise of neoliberal ideology evidenced in monetarism as the leading global economic theory, and the promotion of an individualistic conception of human beings. ${ }^{12}$ The evidence presented to substantiate the declaration of a radical rupture is based on Western Europe, however. ${ }^{13}$ This analysis has we weakness, according to a recent critique by Graf and Priemel. Notions of radical rupture popular in the 1970s are taken at face value, particularly the populist sociology of Daniel Bell. Doering-Manteuffel and Raphael award centre stage to Bell's 
work on 'post-industrial society'. But his proclamation that the inventions of a techno-scientific elite triggered large-scale unemployment of manufacturing workers does not consider that manufacturing had been relocated elsewhere. In fact, even today, workers in China and elsewhere assemble the means of production for 'post-industrial' professions, which gives a very industrial dimension to post-industrial work. ${ }^{14}$

However, this critique only partly identifies the analytical shortcomings that go along with the identification of a radical rupture around 1975. Graf and Priemel have suggested that historians of the recent past should relegate the work of 1970s social scientists to the status of historical sources. ${ }^{15}$ What remains hidden, then, is that even contemporary social scientists spoke out against Bell's clear-cut periodization of world history. The above-mentioned notion of a new international division of labour is an obvious contemporary counterpoint to the notion of post-industrial society.

There is thus a lot more at stake than the question of how to deal with historical sources. Clear-cut periodizations of world history have to do with a more general analytical problem. Modes of regulating capitalist accumulation, such as Fordism, Keynesianism, neoliberalism and post-Fordism, never go uncontested. Therefore, in any given period of world history there is always a plethora of ways of exploiting labourers. An important precondition for the stability of the Fordist/Keynesian tripartite agreement between state, capital and labour (that is, trade unions) throughout much of the post-war era was early Cold War anti-communist witch-hunts. But Keynesians and neoliberals shared anti-communism, and one of the preeminent politicians of the neoliberal era was able to build his career on such witch-hunts. Ronald Reagan, whose 1980s US presidency is often mentioned as a turning point towards neoliberalism in global politics, ${ }^{16}$ was a key figure in the prosecution of presumed communists in Hollywood in the 1950s and central to the anti-union policies of General Electric (GE) during the 1950s and 1960s, one of the first large-scale multinational corporations. ${ }^{17}$ Anti-communist operations were not necessarily to the benefit of the Keynesian regime, although they were very much in line with the managerial ideas of Henry Ford, of course. General Electric paid Reagan for campaigning against trade unions on its factory shop floors all over the United States, and he was also host of a company-sponsored TV show that helped him to nationwide fame. ${ }^{18}$ As has been pointed out elsewhere, GE's efforts should not be studied as the efforts of a single corporation, however large and powerful, but in light of a much wider campaign against the New Deal that was gaining momentum in the 1950 s. ${ }^{19}$ Thus if we want to speak of a Keynesian consensus for the period before 1975 it is important to consider how this consensus was manufactured. It should now be evident that decimating opponents in the trade union movement and elsewhere 
achieved comparative political stability for the Keynesian/Fordist pattern of accumulation, possibly at the cost of opening the door for neoliberal ideology.

Heyom these of neoliberalism is so often attributed to the 1970s when in that same decade Foucault pointed out, in his ground-breaking analysis of the intellectual origins and trajectory of neoliberalism in his 1978-79 lectures at the Collège de France, that New Deal policies were already under attack in the United States and Great Britain during the Second World War. Central figures in these attacks were emigrants of the Freiburg School, such as Friedrich Hayek and Wilhelm Röpke. Their analytical strategy was to depict state intervention and employment programmes as the road to Nazism. ${ }^{20}$ The intellectual trajectory of neoliberalism and the role of individuals and institutions are well studied in the legacy of Foucault. There is thus sufficient work at hand for the history of ideas to dismiss, on empirical grounds, claims that the 1970s was a decade of radical rupture.

But there is little empirical work on the way neoliberal policies were spread and implemented on a global scale. The following is a contribution to filling this gap. The global spread of EPZs will serve to show that the neoliberal thinkers' and businessmen's intellectual crusade for neoliberalism was well reflected in corporate policies and economic actions after the Second World War.

\section{The Emergence of a Prototypical EPZ Regime in Puerto Rico in the 1940s}

The global spread of EPZs did not happen only because, for corporations, the zones were highly attractive destinations for manufacturing relocations. From the beginning, EPZs were also hotspots for experiments and innovation in labour relations, the organization of production processes, and regional and national economic policies.

EPZs were at the forefront of radical changes in the production networks of old and new light consumer electronics, for example. Companies such as the Radio Corporation of America (RCA) and other branches of General Electric established production outlets in EPZs on the Mexican side of the US-Mexican border and in the Shannon Free Zone in Ireland throughout the 1960s. ${ }^{21}$ From the beginning of the 1970s, EPZs attracted ary-ealled South-South connections. Companies from newly industrialized countries (NICs) such as South Korea set up shop in the santr-Mexican zones, while Japanese companies outsourced production to $\mathrm{EPZ}$ s, suchas the Masan Free Zone in South Korea and the Kaoshiung EPZ in Taiwan. ${ }^{22}$ 
From the early days, marketing agencies promoted relocations from industrialised to developing countries and regions. Many Northern corporations producing garments, textiles, light consumer electronics or other commodities that allowed for mobility set up shop in the US South after the Second World War because labour was cheaper and unions were weak. ${ }^{23}$ But such relocations were not limited to the US mainland. At the same time, the United States dependency Puerto Rico radically altered its economic development policies. While these had been firmly based on a New Deal version for this Caribbean colony in the 1930s and throughout the war, the island's ruling Partido Popular set up the first EPZ-style development regime in 1947.

This regime, a 'Puerto Rican lure' in the words of the Wall Street Journal, ${ }^{24}$ offered mainland investors customs- and tax-free production for several years, alongside other government subsidies such as cheap leases for industrial plots, low rents for state-owned factories and, of course, a cheap and docile labour force. The Boston-based consulting corporation Arthur D. Little Inc. (ADL) was hired to promote relocations, and an Office of Information for Puerto Rico in Washington sent out a monthly letter to 14,000 people and institutions and 35,000 brochures to manufacturers, bankers, business writers, and so on in 1946 alone, promoting 'Puerto Rico's potential as a site for textile apparel and other industries' ${ }^{25}$

One of the first investors to set up shop in Puerto Rico was Royal W. Little. It is insightful to follow Little's biography if we want to grasp how the establishment and marketing of the Puerto Rican EPZ contributed to ongoing changes in the landscape of US industrial manufacturing. This brief and indicative summary of the making and unmaking of operations of one of the larger US textile companies in the 1940s and 1950s reveals that patterns often asserted to be genuinely post-1970s were in fact common business practice much earlier.

Royal Little was the nephew of the ADL owner, whose marketing agency had helped in planning, and was later in charge of promoting, the Puerto Rican EPZ. Until 1939, Little had made good profits by manufacturing parachutes and other equipment for the US Army. When he lost those contracts, he set up a new company called Textron, Inc. The ambition was to establish the first vertically integrated synthetic fibre-based textile company. And indeed, after operations started in 1943, Textron expanded rapidly, buying up several spinning mills and other plants in New England. This was unusual, as the US South was the place to invest in those days. But although labour was cheaper in the South and unions were weak, acquisitions in New England meant that a state-imposed quota for raw materials allocated per plant could be obtained. Textron became a successful brand of nationwide renown, selling its produce to 'selected department stores' and 
spending around USD 1 million annually on advertising in magazines, on radio programmes and at the retail level. ${ }^{26}$

Once the war was over, demand fell and quota were less important. The South was now even more attractive and Textron turned away from its New England acquisitions. These had often been textile and garment manufacturers, such as Lonsdale and the Nashua Manufacturing Company (NMC), whose operations dated back to the early nineteenth century. NMC, for example, was subjected to what nowadays social scientists and historians might identify as prototypical neoliberal restructuring. Textron hired a consulting production engineering company that conducted time-motion studies for a period of twelve months. Based on this it was recommended to purchase modern machinery at USD 1 million and to lay off more than 35 per cent of NMC's four thousand workers. Little then took the consultants to see Emile Rieve, the general president of the Textile Workers' Union of America (CIO). He presented Rieve with two options: either operations would be closed down as NMC had much lower profitability than southern mills, or Rieve could accept the restructuring proposals and in this way save 65 per cent of NMC jobs. According to Little's autobiography, Rieve agreed but failed to convince NMC's workforce to do the same. Because Textron then moved on to close down the Nashua plant completely, except for the famous 'Indian Head' blankets brand, a US Senate subcommittee convened a hearing about the closures. ${ }^{27}$

This hearing did not only look at relocations to the US South. Significant shares of production had been moved to Puerto Rico where Textron had set up shop with the support of the 'Fomento Industrial'. This was a New Deal-founded development corporation that was now under the control of Teodoro Moscoso, son of a middle-class pharmacist from the southern city of Ponce. Fomento was selling off several plants owned by the local government to US investors. During New Deal days, these factories had been paid for with US Treasury Department rebates from excise taxes on rum and tobacco exports. ${ }^{28}$ Instead of buying one of these plants, Little got Textron an even better deal. He convinced Moscoso that Fomento should put up USD 4 million for machinery, and Textron would enter into business with USD 1 million as working capital. ${ }^{29}$ As the projected 100 per cent annual return on investment did not materialize for Textron, Puerto Rican operations were subsidized by Fomento in the early 1950s but nevertheless closed down in $1957 .^{30}$

Little's family relations and Textron's company policies add important insights into the actual practice of early post-Second World War neoliberalism in light manufacturing industries to existing works, revealing how US businessmen supported neoliberal think tanks. ${ }^{31}$ The case of Textron shows that present-day terms such as 'runaway shops', used to describe the 
operations of multinational corporations in EPZs and elsewhere since the 1970s, are well applicable to much earlier periods too. ${ }^{32}$

\section{The Global Spread of EPZ Regimes in the 1950s and 1960s}

Importantly, the entangled cases of Textron and Puerto Rico are not single cases but, on my reading, emblematic of a pattern of diffusion of the global EPZ regime. A Ford Foundation-funded biography of the above-introduced Fomento Industrial chairman, Teodoro Moscoso, speaks of ten thousand visits by foreign officials to Puerto Rico that various US ministries arranged after 1947. ${ }^{33}$ This impressive number of inspections of the Puerto Rican success story might be genuine, because successive US administrations promoted the island's neoliberal export-oriented industrialization drive as blueprints for successful development policies throughout the Third World. At the onset of the Cold War, the Truman administration promoted capitalist-style development under the 'Point Four' programme, announced by Truman in early 1949 and implemented in 1950. 'Point Four' development assistance to Egypt and many other nations replicated Puerto Rican policies as best-practice example of how to achieve export-oriented growth. ${ }^{34}$ Indeed, contemporary debates on tax evasion, runaway shops and superexploitation in export processing zones have precursors in the 1950s, when there was widespread debate among economists and social scientists about the upsides and downsides of Puerto Rican export-oriented development policies based on tax and customs exemptions and strong local government support for investors. ${ }^{35}$ In the following decade, the Kennedy administration set up the 'Alliance for Progress' after the failures of the Cuban crisis. Again, tax exemptions and state-support for export-oriented industrialization policies ranked high on the list of US development-policy recommendations. th fat, many Puerto Rican politicians and bureaucrats now became US envoys to Latin America in an effort to give the development policy success a human face, and Moscoso was appointed ambassador to Venezuela. ${ }^{36}$

Although Little's Textron left Puerto Rico in 1957, this did no harm to the fortunes of his uncle's company Arthur D. Little, Inc. and their consulting and marketing activities in Puerto Rico and elsewhere. In 1957, Richard Bolin took over as head of the ADL office in San Juan and stayed until $1962,{ }^{37}$ when he moved on and set up his own consulting corporation called 'International Parks'. Possibly subcontracting for ADL with this company, he obtained several consulting contracts with cities on the Mexican-US border. This was a few years prior to the large-scale 'Border Industrialization Programme' of the Mexican federal state that established what would later become known as the 'maquiladora' industry of bonded factories, with the 
usual EPZ incentives such as tax and customs exemptions, state-funded industrial estates and zones, oppressive anti-unionization policies, and so forth in several border cities. In a book-length study of the Mexican border region inspired by Fröbel, Heinrich and Kreye's NIDL paradigm, anthropologist María Patricia Fernández-Kelly defines this programme as 'the last in a series of systematic efforts' to industrialize that region dating back to the granting of free-trade privileges for bonded warehouses in the 1930s. ${ }^{38}$

While Bolin's work laid the foundations for the maquiladoras in Ciudad de Juarez, Taiwan built an EPZ as part of the Kaoshiung international container harbour, with successive funding from US AID, the World Bank and the United Nations Technical Assistance Programme from the early 1960s. ${ }^{39}$ India designed a somewhat similar strategy as early as 1951, when first plans were made for a 'foreign trade zone' adjacent to the container port development in Kandla. Port and EPZ were to compete with Karachi, which since partition was part of Pakistan. To provide employment for refugees in a planned settlement called Gandhidham, development plans were drawn up for that remote region. The Kandla Foreign Trade Zone opened its gates just a few months before Kaoshiung EPZ, thus making this Asia's first EPZ. ${ }^{40}$

Elsewhere, it did not take fourteen years from EPZ planning to EPZ opening. The Shannon Free Zone became operational after a short planning phase in 1959 in an effort to keep the remote so-called 'mid-west' region of the Republic of Ireland afloat. Most stopovers on transatlantic flights were routed through Shannon after the Second World War but now that technological advances allowed planes to go all the way to European destinations, business was dwindling, and the airport duty-free regime that had been set up for the sale of alcoholic beverages, tobacco and other luxury commodities was extended to manufacturing. Brendan O'Reagan, customs comptroller at Shannon and owner and director of several public-private companies doing most of the airport business, had acquired knowledge of EPZ operations during visits to Puerto Rico and also to the Zona Libre in Colon Harbour, Panama, where an EPZ regime had been established in the 1950s. ${ }^{41}$

Despite all these activities across the globe, the labelling of the zones was rather open, ranging from export processing zone, free zone, Spanishlanguage terms such as 'zona libre' and 'zona franca', to foreign trade zone in India. Academic writings of the 1950s and 1960s, on Puerto Rico, for example, discussed tax and customs incentives, and also touched on the emergence of what sociologists nowadays call a transnational capitalist class of entrepreneurs, consultants and celebrities who were meeting in glamorous hotels such as the Caribe Hilton in San Juan. ${ }^{42}$ But, ironically, it was left to a United Nations' organization that would otherwise be known for very different policies to come up with a coherent label for the export-oriented development regime that was established on that Caribbean island in 1947. 
The growing political impact of the non-aligned movement in the 1960s led to the establishment of new UN agencies such as the United Nations Commission on Trade and Development (UNCTAD), headed by famous Latin American economist Rául Prebisch, the United Nations Development Programme (UNDP) and the United Nations Industrial Development Organization (UNIDO). Independent scholars have not written detailed histories of these organizations yet, and it is beyond the scope of this chapter to make even a minor effort in this direction. Evident from existing summaries is that the important debates about setting up these agencies took place in the UN Economic and Social Council (ECOSOC). ECOSOC resolution 751 (XXIX) of April 1960 established an Industrial Development Committee (IDC), whose fourth session, in 1964, unanimously voted for recommending the creation of an autonomous organization, UNIDO, to the UN General Assembly. ${ }^{43}$

The foundational work of the IDC-associated Centre for Industrial Development (CID) included surveying the world for models of industrialization. The covering letter to a questionnaire distributed to member states via the office of the UN Secretary General in September 1966 highlighted the potential of export industries to circumvent price fluctuations of primary commodity exports on the global market, as identified in ECOSOC resolution 1178 (XLI). Responses to the questionnaire reveal, for example, that Cyprus ${ }^{44}$ and Malta ${ }^{45}$ both had EPZ-like regimes in place from 1959 and even earlier. Other countries, such as the Philippines, were developing EPZs with US AID funding. ${ }^{46}$ Also, one member of the CID made efforts to bring about a first global survey of EPZ activities in September 1966. Correspondence available on this in the UN archival record is limited to an exchange of letters with KEPZ, however. ${ }^{47}$

Responses to the CID questionnaire on general export-oriented policies figured prominently in the 1967 proceedings of the first session of UNIDO's general assembly, the 'Industrial Development Board' (IDB). A '[p]rogress report on steps taken by developing countries to develop and establish export-oriented industries' to the IDB included extended reference to EPZ-like regimes, and suggested UNIDO should recommend replicating them. ${ }^{48}$ Accordingly, one of fifteen groups in UNIDO's initial institutional set-up operated under the heading 'Export Promotion' (EP) as part of the 'Industrial Policies and Programming Division'. This group conducted the first concise global survey on EPZ activities in 1970. In February that year the first letters to the administrations of known free zones, free trade ports, export processing zones and so forth were sent out. Throughout that year, correspondence was spread more widely as this global mailing activity also became the centrepiece of promoting UNIDO EP services to national development agencies and ministries. ${ }^{49} \mathrm{~A}$ first technical assistance mission to 
Mauritius had been commissioned and conducted in 1969. This was regularly mentioned in marketing-style letters to ministries and development authorities, as the head of EP, William Tanaka, sought to acquire further technical assistance requests from member states. ${ }^{50}$

At the same time, correspondence for the survey established contacts with the US Department of Commerce, whose executive secretary of the Foreign Trade Zones Board would be a regular speaker at UNIDO workshops training 'Third World' officials how to set up export processing zones. Established EPZs in Shannon and Barranquilla, Colombia, hosted these workshops. ${ }^{51}$ Tanaka had made contact with these zones' administrations during that global survey as well. The Shannon Free Airport Development Corporation (SFADCo) realized first that UNIDO's EP group was an ideal platform for establishing something bigger, and entered negotiations to become the central UNIDO outpost for EPZ promotion. SFADCo affiliate Peter Ryan followed Tanaka as head of UNIDO's EP and hired Shannon entrepreneur Tom Kelleher to write a handbook on Export Processing Zones. Published in 1976, one year before Fröbel, Heinrich and Kreye's NIDL book, that UNIDO handbook laid out in detail how to set up an $\mathrm{EPZ}$, including templates for organizational structures from EPZs in Bataan in the Philippines, Masan in South Korea, and Shannon. ${ }^{52}$ Since the first UNIDO international workshop for setting up EPZs held in Shannon in 1972, the label 'export processing zone' was standard for UNIDO, and applied in hundreds of technical assistance missions.

\section{Concluding Remarks: Capitalism, Regulation, and Anti-Social Movements}

In this chapter, I have established the case of the global spread of export processing zones (EPZs) to argue that the 1970s may well be regarded as a 'decade of consolidation', because the global division of labour in light industrial manufacturing had previously been in transition. The fact that EPZs became the most prominent economic development policy for attracting investment in light industrial manufacturing, ultimately dominating this in the 2000s, had surely not been evident when Puerto Rico set up an EPZ-like regime in 1947. From a US perspective, it may not even have been intended that EPZs took centre stage in a political project called 'development' that sought to convince newly independent nation states of the benefits of alliances with the capitalist block during the era of decolonization..$^{53}$ Crucially, however, the global spread of EPZs shows that it would be wrong to assume that a global Keynesian or Fordist consensus, or practice, ever existed, as Giovanni Arrighi does when he identifies development as a 'global new deal'. ${ }^{54} \mathrm{My}$ 
findings instead underline a much broader analytical stance: capitalism here has been analysed on a global scale. This reveals that an analysis of capitalism as driven by a singular pattern of accumulation, for example, unnecessarily narrows our perspective.

from a global perspective on the spread of EPZs, however, there is strong evidence that the 1970s should be regarded as a period of consolidation. This is not to say that nothing changed during that decade. The regime established in Puerto Rico in 1947, which subsequently spread across the world, received a standard label of 'export processing zone' that came about via the work of one group within the newly established UN agency, UNIDO. Workshops, a handbook and hundreds of technical assistance missions (often conducted by Irish consultants affiliated to or directly employed by the Shannon Free Airport Development Corporation) then spread the label 'export processing zone', and even more so the pattern of regulating capitalist accumulation. Other terminologies spread as well: for example, the road where the administration headquarters of the Kingston (Jamaica) Free Trade Zone are located is called 'Shannon Drive'. The fact that Jamaica's first EPZ, established in 1976, is called 'Free Zone' indicates that the label 'EPZ' did not instantly become standard throughout the world. Importantly for my argument, however, standardization has worked to the extent that since the 1970s thorough academic studies such as Fröbel, Heinrich and Kreye's book, as well as policy guidelines published by the World Bank, do use 'EPZ'.

The example I have given in this chapter does not, of course, qualify as an outright contradiction of the important works on the 1970s by historians of the recent past. No matter whether that decade is seen as one of radical rupture or one of continuity, the empirical substance of works on changes in industrially advanced Western countries should not be disputed. What is important, however, is to use the notion of the 1970s as a decade of consolidation to ask how the 1970s looked for those people who took the jobs of manufacturing workers in industrially advanced countries, as corporations increasingly shifted production to EPZs.

For the small island nation state Mauritius, I have argued elsewhere that the 1970s saw the percentage of women in the labour force rising as EPZ production spread. Again though, a historical analysis of labour relations reveals that gendered exploitation is not a unique feature of EPZs, and only emerged in a supposedly 1970s radical rupture towards flexible accumulation. This has regularly been stated in anthropological studies labelling female EPZ workers as 'neophyte', because zone factories were the first industrial ventures to help women in developing countries to enter the labour market. ${ }^{55}$ In Mauritius, however, the colonial sugar industry already had significant female labour and gendered exploitation, and there is strong 
evidence that in many other former plantation colonies setting up EPZs, we find a continuation of the gendered exploitation that existed in the colonial era, in part sustained by local 'myth[s] of the male breadwinner', which continue to deny the wage labour contribution of women to households in Puerto Rico and elsewhere. ${ }^{56}$

Similarly, most newly established EPZ companies were actually joint ventures of foreign investors and those Mauritian corporations that had controlled the colonial economy in sugar production and beyond. ${ }^{57}$ In Mauritius then, we find further patterns of consolidation in the 1970s when the transition from colonial to postcolonial exploitation of workers by the very same capitalists came full circle.

The above arguments and empirical evidence show that in order to identify radical ruptures in national and world history there is a need for detailed and comparative global research, and an analysis that reconsiders capitalism from the perspective of world history as a history of contradictions and a constant balancing of the demands of competing (anti-)social movements. For a particular mode of regulating capitalism is always contested, even from within the ranks of national and international bourgeoisies, which organize in anti-social movements and quarrel over the best way to exploit workers and consolidate a particular pattern of regulating capitalist exploitation. A strong focus on inequality and related issues such as exploitation, accumulation and class division - may therefore help us to show how radical rupture for some (e.g. German workers losing their job in the 1970s) is continuity for others (e.g. Mauritian workers experiencing a continuity of colonial labour regimes in postcolonial EPZs). Building on the case of the global spread of EPZs discussed in this chapter, a global historical analysis interested in the entanglements of exploitation will, most likely, reveal how in many other sectors - international finance and the tourism industry, to name two - the 1970s was a period of consolidation, as one among several contested options for capitalist accumulation became dominant.

Patrick Neveling works at the Department of Development Studies, School of Oriental and African Studies/University of London. He has lead-edited special issues for Sociologus, Etnográfica and Contributions to Indian Sociology, and co-edited a book on Tradition Within and Beyond the Framework of Invention (Halle University Press). His work addresses the historical-political economy of capitalism, with a special focus on the global spread of export processing zones/special economic zones and on the small island state of Mauritius, and he is currently finishing a book on a global historical anthropology of special economic zones. 


\section{Notes}

Research for this publication was supported by the Swiss National Science Foundation (Grant Nos: 126642 and 140848). The author would like to thank the staff members at the General Archives of Puerto Rico and at the archives of the United Nations Industrial Development Organization for their kind support.

1. Anselm Doering-Manteuffel and Lutz Raphael, Nach dem Boom: Perspektiven auf die Zeitgeschichte seit 1970, 2nd rev. edn (Göttingen, 2010); Niall Ferguson, The Shock of the Global: The 1970s in Perspective (Cambridge, MA, 2010).

2. See, for example, David Harvey, The Condition of Postmodernity: An Enquiry into the Origins of Cultural Change (Oxford and Cambridge, MA, 1990).

3. See Knud Andresen, Ursula Bitzegeio and Jürgen Mittag (eds), Nach dem Strukturbruch?: Kontinuität und Wandel von Arbeitsbeziehungen und Arbeitswelt(en) seit den 1970er-Jahren (Bonn, 2011).

4. See, for example, Georg Baca, 'Legends of Fordism: Between Myth, History, and Foregone Conclusions', in The Retreat of the Social: The Rise and Rise of Reductionism, ed. Bruce Kapferer (New York and Oxford, 2005), 31-46; June Nash, 'Post-Industrialism, Post-Fordism, and the Crisis in World Capitalism', in Meanings of Work: Considerations for the Twenty-First Century, ed. Frederik C. Gamst (Albany, NY, 1995), 189-211.

5. E.g. Patrick Neveling, 'Export Processing Zones and Global Class Formation', in Anthropologies of Class: Power, Practice, and Inequality, ed. James Carrier and Don Kalb (Cambridge, 2014), 171-96; idem, 'Export Processing Zones, Special Economic Zones and the Long March of Capitalist Development Policies during the Cold War', in Negotiating Independence: New Directions in the History of Decolonisation and the Cold War, ed. Leslie James and Elisabeth Leake (London, 2015), 63-84.

6. Recent reports by international organizations indicate the global spread of EPZs. While assessments differ regarding the upsides and downsides of EPZ development, there is consensus on global employment figures counting close to 70 million workers in EPZs worldwide for the late 2000s. For 2007, an in-focus group on EPZs set up by the International Labour Office counted more than 3,500 EPZs in more than 130 countries, employing more than 60 million workers. This count includes the widest possible spectrum of zones, as it not only considers 'classic' manufacturing zones but also offshore-banking centres, free ports and so on. See Jean-Pierre Singa Boyenge, 'ILO Database on Export Processing Zones (Revised)', ILO Working Papers 251 (2007), http://www.ilo.org/public/english/dialogue/sector/themes/ epz/epz-db.pdf. A 2008 investor and donor guide published by the International Finance Corporation/The World Bank applies different criteria and uses the denomination 'special economic zones' (although the denomination 'EPZ' often slips into the text and is used synonymously). See Gokhan Akinci, James Crittle, and FIAS/The World Bank Group, Special Economic Zones: Performance, Lessons Learned, and Implications for Zone Development (Washington DC, 2008). The count is 266 zones for 'industrialized countries' and 2,301 zones for 'developing and transition countries' (ibid., 13, 18). Direct zone employment is estimated at 68.4 million for 2008 (ibid., 34).

7. See Folker Fröbel, Jürgen Heinrichs and Otto Kreye, Die neue internationale Arbeitsteilung: strukturelle Arbeitslosigkeit in den Industrieländern und die Industrialisierung der Entwicklungsländer (Reinbek bei Hamburg, 1977).

8. This is the subtitle of the English-language publication of their work. See Folker Fröbel, Jürgen Heinrichs and Otto Kreye, The New International Division of Labour: Structural Unemployment in Industrialised Countries and Industrialisation in Developing Countries (Cambridge, 1981).

9. For example, Doering-Manteuffel and Raphael, Nach dem Boom. 
10. For the social sciences see Nash, 'Post-Industrialism'. For summaries of this critique, see Patrick Neveling, 'Einleitende Überlegungen: Wissen um Veränderung: Entwicklung, Geschichte, sozialer Wandel (Engl.: Introductory Remarks: The Production of Knowledge about Change: Development, History, Social Transformation)', Sociologus 60(1) (2010), 1-14. Also idem, 'Flexible Capitalism and Transactional Orders in Colonial and Postcolonial Mauritius: A Post-Occidentalist View', in Flexible Capitalism: Exchange and Ambiguity at Work, ed. Jens Kjaerulf (Oxford, 2015). Reference to the territorial limitations of Bell's analysis is made by historians Rüdiger Graf and Kim Christian Priemel, 'Zeitgeschichte in der Welt der Sozialwissenschaften: Legitimität und Originalität einer Disziplin', Vierteljahreshefte für Zeitgeschichte 59(4) (2011): 485.

11. For this focus, see Doering-Manteuffel and Raphael, Nach dem Boom; and Harvey, The Condition.

12. Doering-Manteuffel and Raphael, Nach dem Boom, 31.

13. Ibid., 38.

14. Graf and Priemel, 'Zeitgeschichte', 485.

15. Ibid., 479.

16. See Doering-Manteuffel and Raphael, Nach dem Boom, 29-36.

17. For an analysis of workers' support for anti-communist propaganda, see June C. Nash, From Tank Town to High Tech: The Clash of Community and Industrial Cycles (New York, 1989).

18. Kim Phillips-Fein, Invisible Hands: The Businessmen's Crusade against the New Deal (New York and London, 2009), 111-14.

19. Ibid. For an early assessment of this campaign from a social science perspective, see M. Patricia Marchak, The Integrated Circus: The New Right and the Restructuring of Global Markets (Montreal and Buffalo, NY, 1991), 111-15.

20. Michel Foucault, Michel Senellart and Collège de France, The Birth of Biopolitics: Lectures at the Collège de France, 1978-79 (Basingstoke and New York, 2008), 101-11.

21. For RCA, see Jefferson Cowie, Capital Moves: RCA's Seventy-Year Quest for Cheap Labor (Ithaca, NY, 1999). For Shannon, see Neveling, 'EPZs and Global Class Formation'.

22. S. Watanabe, 'Constraints on Labour-Intensive Export Industries in Mexico', International Labour Review 109 (1974): 23-45. Seung-Kyung Kim, Class Struggle or Family Struggle? The Lives of Women Factory Workers in South Korea (Cambridge, 1997).

23. See Baca, 'Legends'.

24. M.M. Diefenderrer (Staff Correspondent of the Wall Street Journal), 'Puerto Rican Lure', Wall Street Journal, 7 June 1946.

25. See Office of Information for Puerto Rico/Washington. 'Annual Report' San Juan. 1946, Tarea 96-20, Puerto Rico General Archives (Documents Section), Oficina del Gobernador.

26. Royal Little, How to Lose $\$ 100,000,000$ and Other Valuable Advice, 1st edn (Boston, 1979), 74.

27. Ibid.

28. See Neveling, 'EPZs and Global Class Formation'.

29. Ibid see also Little, How to Lose, 82-83.

30. Julio Rivera, 'Reabrirá en Ponce Fábrica de Textron', El Mundo, 27 September 1957.

31. See Phillips-Fein, Invisible.

32. This has, of course, been well captured for the US South in Baca, 'Legends'.

33. A.W. Maldonado, Teodoro Moscoso and Puerto Rico's Operation Bootstrap (Gainesville, FL, 1997).

34. Neveling, 'EPZs and Global Class Formation'. 
35. For the repercussions of this debate in academic journals, see an exchange between two economic sociologists/development economists: Gordon K. Lewis, 'Puerto Rico: A Case Study of Change in an Underdeveloped Area', The Journal of Politics 17(4) (1955): 614-50. David F. Ross, 'Gordon Lewis on Puerto Rico's Development Program', The Journal of Politics 19(1) (1957): 86-100.

36. Leigh Miller, 'Oral History Interview with Teodoro Moscoso for the John F. Kennedy Library', Boston, 18 May 1964, Moscoso, Teodoro JFK Interview \#1, \#2, \#3, John F. Kennedy Presidential Library and Archives.

37. Arthur D. Little Inc. 'New Puerto Rican Office is Opened', Boston, Massachusetts. Winter 1957, Series 7, Box 5, MC 579, History Earl Stevenson, MIT Archives, Arthur D. Little, Inc.

38. María Patricia Fernández-Kelly, For We Are Sold, I and My People: Women and Industry in Mexico's Frontier, SUNY series in the anthropology of work (Albany, NY, 1983), 23-26.

39. See W.B. Leonard (Acting Commissioner for Technical Assistance), 'Letter Concerning: China - Request of the Government of the Republic of China for Four Experts under WCRF', New York, 19 May 1965, S-0175-0308, United Nations Archives and Records Managment.

40. For a summary of the Kandla story, see Patrick Neveling, 'Structural Contingencies and Untimely Coincidences in the Making of Neoliberal India: The Kandla Foreign Trade Zone, 1965-1991', Contributions to Indian Sociology 48(1) (2014): 17-43.

41. For a summary of the Shannon story, see Neveling, 'EPZs and Global Class Formation'.

42. See Ross, 'Gordon Lewis', 88.

43. Youry Lambert, The United Nations Industrial Development Organization: UNIDO and Problems of International Economic Cooperation (Westport, CT, 1993), 7-21.

44. Cyprus Ministry of Foreign Affairs/Ministry of Commerce \& Industry. 'Letter to the Secretary-General of the United Nations', New York, 5 December 1966, S-0450-0555, UN Archives and Records Management, Economic Affairs.

45. Permanent Mission of Malta to the United Nations. 'Answers to Questionnaire to the Secretary-General of the United Nations, New York', New York, 22 November 1966, S-0450-0555, UN Archives and Records Management, Economic Affairs.

46. Rizalino R. Pablo (Executive Director Republic of the Philippines National Economic Council). 'Letter to the Secretary-General of the United Nations, New York', 16 November 1966, S-0450-0555, UN Archives and Records Management, New York, Economic Affairs.

47. Cf. Council for International Economic Cooperation and Development S.Y. Dao (Secretary General, Executive Yuan); 'Letter to Dr W.M. Svoboda, Room 3277, United Nations, New York', New York, 18 October 1966, S-0450-0555, UN Archives and Records Management, Economic Affairs.

48. Executive Director of the United Nations Industrial Development Organization. 'Progress Report on Steps Taken by Developing Countries to Develop and Establish ExportOriented Industries', Vienna, 1967, ID/B/8, English, United Nations Industrial Development Organization Archive.

49. For the correspondence, see United Nations Industrial Development Organization Archives, Folder TS 221/2 (21).

50. For example, William H. Tanaka. 'Letter to Teodore Q. Pena, Commissioner and Executive Officer, Foreign Trade Zone Authority, Port Area, Manila', Vienna, 16 April 1970, Folder TS 221/2 (21), United Nations Industrial Development Organization Archive.

51. See United Nations Industrial Development Organization. 'Training Workshop in Industrial Free Zones as Incentives to Promote Export-Oriented Industries, Shannon, 1972. Programme of Work', Vienna, 1972, 003166, United Nations Industrial Development 
Organization Archives, Industrial Development Abstracts; and United Nations Industrial Development Organization. 'Regional Expert Working Group Meeting on Industrial Free Zones, Barranquilla, 1974', Vienna, 1974, 005642, United Nations Industrial Development Organization Archives, Industrial Development Abstracts.

52. Tom Kelleher, 'Handbook on Export Processing Zones', Vienna, 1976, 007125, United Nations Industrial Development Organization Archives, Industrial Development Abstracts, Appendix 5.

53. There would be a lot more to say about the role of EPZs in the era of decoloniza-

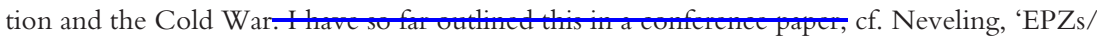
Cold War'.

54. Giovanni Arrighi, 'The Global Market', Journal of World Systems Research 2 (1997): 247.

55. E.g. Aiwha Ong, 'The Gender and Labor Politics of Postmodernity', Annual Review of Anthropology 20 (1991): 290-91.

56. Helen Icken Safa, The Myth of the Male Breadwinner: Women and Industrialization in the Caribbean (Boulder, CO, 1995).

57. See Patrick Neveling, 'Manifestationen der Globalisierung. Kapital, Staat und Arbeit in Mauritius, 1825-2005' (DPhil, Martin Luther University, Halle-Wittenberg, 2012).

\section{Bibliography}

Akinci, Gokhan, James Crittle and FIAS/The World Bank Group, Special Economic Zones: Performance, Lessons Learned, and Implications for Zone Development (Washington DC, 2008).

Andresen, Knud, Ursula Bitzegeio and Jürgen Mittag (eds), Nach dem Strukturbruch?: Kontinuität und Wandel von Arbeitsbeziehungen und Arbeitswelt(en) seit den 1970er-Jahren (Bonn, 2011).

Arrighi, Giovanni, 'The Global Market', Journal of World Systems Research V(2) (1997): 217-251.

Baca, Georg, 'Legends of Fordism: Between Myth, History, and Foregone Conclusions', in The Retreat of the Social: The Rise and Rise of Reductionism, ed. Bruce Kapferer (New York and Oxford, 2005), 31-46.

Cowie, Jefferson, Capital Moves: RCA's Seventy-Year Quest for Cheap Labor (Ithaca, NY, 1999).

Doering-Manteuffel, Anselm, and Lutz Raphael, Nach dem Boom: Perspektiven auf die Zeitgeschichte seit 1970, 2nd rev. edn (Göttingen, 2010).

Ferguson, Niall, The Shock of the Global: The 1970s in Perspective (Cambridge, MA, 2010).

Fernández-Kelly, María Patricia, For We Are Sold, I and My People: Women and Industry in Mexico's Frontier (Albany, NY, 1983).

Foucault, Michel, Michel Senellart and Collège de France, The Birth of Biopolitics: Lectures at the Collège de France, 1978-79 (Basingstoke and New York, 2008).

Fröbel, Folker, Jürgen Heinrichs and Otto Kreye, Die neue internationale Arbeitsteilung: strukturelle Arbeitslosigkeit in den Industrieländern und die Industrialisierung der Entwicklungsländer (Reinbek bei Hamburg, 1977). English translation: The New International Division of Labour: Structural Unemployment in Industrialised Countries and Industrialisation in Developing Countries (Cambridge, 1981).

Graf, Rüdiger, and Kim Christian Priemel, 'Zeitgeschichte in der Welt der Sozialwissenschaften: Legitimität und Originalität einer Disziplin', Vierteljahreshefte für Zeitgeschichte 59(4) (2011): 479-508.

Harvey, David, The Condition of Postmodernity: An Enquiry into the Origins of Cultural Change (Oxford and Cambridge, MA, 1990).

Kim, Seung-Kyung, Class Struggle or Family Struggle? The Lives of Women Factory Workers in South Korea (Cambridge, 1997). 
Lambert, Youry, The United Nations Industrial Development Organization: UNIDO and Problems of International Economic Cooperation (Westport, CT, 1993).

Lewis, Gordon K., 'Puerto Rico: A Case Study of Change in an Underdeveloped Area', in The Journal of Politics 17(4) (1955): 614-50.

Little, Royal, How to Lose \$100,000,000 and Other Valuable Advice, 1st edn (Boston, 1979).

Maldonado, A.W., Teodoro Moscoso and Puerto Rico's Operation Bootstrap (Gainesville, FL, 1997).

Marchak, M. Patricia, The Integrated Circus: The New Right and the Restructuring of Global Markets (Montreal and Buffalo, NY, 1991).

Nash, June C., From Tank Town to High Tech: The Clash of Community and Industrial Cycles (New York, 1989).

'Post-Industrialism, Post-Fordism, and the Crisis in World Capitalism', in Meanings of Work: Considerations for the Twenty-First Century, ed. Frederik C. Gamst (Albany, NY, 1995), 189-211.

Neveling, Patrick, 'Einleitende Überlegungen: Wissen um Veränderung: Entwicklung, Geschichte, sozialer Wandel' [Introductory Remarks: The Production of Knowledge about Change: Development, History, Social Transformation], Sociologus 60(1) (2010): $1-14$.

'Manifestationen der Globalisierung: Kapital, Staat und Arbeit in Mauritius, 18252005' (DPhil, Martin Luther University, Halle-Wittenberg, 2012).

— - 'Structural Contingencies and Untimely Coincidences in the Making of Neoliberal India: The Kandla Foreign Trade Zone, 1965-1991', Contributions to Indian Sociology 48(1) (2014): 17-43.

, 'Export Processing Zones and Global Class Formation', in Anthropologies of Class: Power, Practice, and Inequality, ed. James Carrier and Don Kalb (Cambridge, 2015), 164-82.

, 'Export Processing Zones, Special Economic Zones and the Long March of Capitalist Development Policies during the Cold War', in Negotiating Independence: New Directions in the History of Decolonisation and the Cold War, ed. Leslie James and Elisabeth Leake (London, 2015), 63-84.

, 'Flexible Capitalism and Transactional Orders in Colonial and Postcolonial Mauritius: A Post-Occidentalist View', in Flexible Capitalism: Exchange and Ambiguity at Work, ed. Jens Kjaerulf (Oxford, 2015), 207-34.

Ong, Aiwha, 'The Gender and Labor Politics of Postmodernity', Annual Review of Anthropology 20 (1991): 279-309.

Phillips-Fein, Kim, Invisible Hands: The Businessmen's Crusade against the New Deal (New York and London, 2009).

Ross, David F., 'Gordon Lewis on Puerto Rico's Development Program', The Journal of Politics 19(1) (1957): 86-100.

Safa, Helen Icken, The Myth of the Male Breadwinner: Women and Industrialization in the Caribbean (Boulder, CO, 1995).

Singa Boyenge, Jean-Pierre, 'ILO Database on Export Processing Zones (Revised)', ILO Working Papers 251 (2007), http://www.ilo.org/public/english/dialogue/sector/themes/ epz/epz-db.pdf.

Watanabe, S., 'Constraints on Labour-Intensive Export Industries in Mexico', International Labour Review 109 (1974): 23-45. 